\title{
DEVELOPMENT OF BACTERIA OF NITROGEN CYCLE IN THE RHIZOSPHERE OF WINTER WHEAT PLANTS UNDER THE INFLUENCE OF DIFFERENT FERTILIZERS BACKGROUNDS AND PRE-SOWING SEEDS BACTERIZATION
}

\author{
Kovpak P.V., Volkogon E.I., Zhurba M.A., Shtanko N.P., Larchenko I.V. \\ Institute of Agricultural Microbiology and Agricultural Production NAAS \\ 97, Shevchenko str., Chernihiv, 14027, Ukraine \\ E-mail: polyakovpak@rambler.ru
}

The paper depicts the research results of development of bacteria of the nitrogen cycle in the root zone of winter wheat plants (variety Sonechko) under the use of microbial preparation Polymyxobacterin and different doses of mineral fertilizers. It was established that split application of fertilizers at doses that do not exceed $N_{60} P_{60} K_{60}$ and pre-sowing seeds bacterization had optimized the composition of microbial associations in the root zone of plants. The increase of fertilizers doses was followed by the negative changes in the number of bacteria of different functional groups. wheat.

Key words: bacteria, that transform nitrogen compounds, fertilizers, Polymyxobacterin, winter

Nitrogen has the biggest impact on the among all major nutrient elements on the plant productivity and quality of the crop in all soil-climatic zones of Ukraine. Thus, in accordance to the general data available the recoupment of one kilogram of nitrogen in increments of winter wheat yield ranges from 3 to $5 \mathrm{~kg}$ of grain in the steppe zone and from 7 to $9 \mathrm{~kg}$ - in Forrest Steppe and Polissya zones [1].

In recent decades, the notable success in the study of the peculiarities of the biological transformation of nitrogen in soils was achieved changing the understanding of the contribution of soil microorganisms in the general circulation of nitrogen in the biosphere. However, new knowledge has not yet been taken into account when developing strategies that address important practical problems of mankind, including food security of the world population [2].

Microorganisms play the main role in transformation of nitrogen. Insufficient attention to the microbiological factor of nitrogen transformation in the soil is one of the reasons of unbalanced plants supply with nitrogen, excessive accumulation of nitrate in the products, low efficiency of nitrogen fertilizers use, massive pollution of biosphere with nitrogen oxides [3]. In this context, the aim of given research was to study the number of bacteria involved in the nitrogen cycle in the root zone of winter wheat plants under the influence of fertilizers and such an important correction factor of microbial communities in the root zone of plants as a pre-sowing seeds bacterization.

Materials and methods. The research was conducted during 2011-2013, on winter wheat plants of Sonechko variety in a stationary field experiment (short crop rotation system) of the Institute for Agricultural Microbiology and Agricultural Production NAAS on meadow black soils containing 2.12\% 
of humus, $95.2 \mathrm{mg} / \mathrm{kg}$ of easily hydrolyzed nitrogen, $226 \mathrm{mg} / \mathrm{kg}$ of phosphorus, $108 \mathrm{mg} / \mathrm{kg} \mathrm{of}$ exchangeable potassium; $\mathrm{pH}_{\text {salt }}$ - 5.30. Experiment scheme had the following options: 1 - without fertilizer (control); $2-\mathrm{N}_{30} \mathrm{P}_{30} \mathrm{~K}_{30}\left(\mathrm{~N}_{20}+\mathrm{N}_{10}\right.$ in autumn, at tillering stage); $3-\mathrm{N}_{60} \mathrm{P}_{60} \mathrm{~K}_{60}\left(\mathrm{~N}_{20}+\mathrm{N}_{40}\right.$ in autumn, at tillering stage); $4-\mathrm{N}_{90} \mathrm{P}_{90} \mathrm{~K}_{90}\left(\mathrm{~N}_{20}+\mathrm{N}_{40}\right.$ in autumn, at tillering stage $+\mathrm{N}_{30}$ in tubing stage); 5-8 - same variants + bacterization. Plots area $-86.4 \mathrm{~m}^{2}$ (7.2 x 12.0), repetition of the experiment - four fold. General agriculture cultivation technologies used for winter wheat in Polissya region were performed. Pre-sowing bacterization of winter wheat seeds was performed according to the SOU 01.1137-782:2008 using microbial preparation Polymyxobacterin [4].

Microbiological analysis of rhizosphere soil samples were taken during the following stages of wheat plants ontogenesis: tubing, flowering and milky-wax ripeness. The number of ammonifier bacteria were determined by dilutions method of studied suspension on meat peptonic agar (MPA). The number of organisms capable of utilizing mineral forms of nitrogen were determined on starch-ammonium agar (SAA) [5]. The number of nitrogen fixing and denitrifying bacteria was determined by standard methods [5-7].

Field experiments and statistical analysis of the results were performed by conventional methods [8].

Results and discussion. Analysis of the research results had shown that formation peculiarities of different groups of microorganisms of nitrogen cycle in the rhizosphere of wheat plants were similar throughout all years of study, although had differ in absolute values.

Thus, the dynamics changes of microorganisms' number in these niches in 2013 had indicated that number of ammonifier bacteria had increased along with the increasing doses of mineral fertilizers, especially in variants with Polymyxobacterin (Fig. 1). At the beginning of the growing season the number of named microorganisms had increased from 17.3 million / g soil $\left(\mathrm{N}_{60} \mathrm{P}_{60} \mathrm{~K}_{60}\right)$ to 21.8 million / g soil in variant with microbial preparation on $\mathrm{N}_{60} \mathrm{P}_{60} \mathrm{~K}_{60}$ background. At flowering stage the number of ammonifiers in control variant was 12.9 million / g soil while in variant with Polymyxobacterin - 19.6 million / g soil. Also, the intensive development ammonifier bacteria was observed in the variant with microbial preparation on a background of the highest dose of fertilizers $\left(\mathrm{N}_{90} \mathrm{P}_{90} \mathrm{~K}_{90}\right)$ and was 29.1 million / g soil, whereas in variant without bacterization - 22.2 million / g soil. At the end of the growing season the number of bacteria in variants with minimal mineral fertilizers dozes $\left(\mathrm{N}_{30} \mathrm{P}_{30} \mathrm{~K}_{30}\right)$ was 10.5 million / $\mathrm{g}$ soil and had risen to 15.9 million / g soil in variant with Polymyxobacterin. The growth of ammonifier microorganisms in rhizosphere soil under the use of Polymyxobacterin is associated with the higher amount of root exudates of bacterized plants. According to the literature the composition of root exudates may have higher amount of organic nitrogen compounds depending on fertilization background [8].

It was established that the number of bacteria that utilize mineral nitrogen in the rhizosphere soil of winter wheat plants was also increasing along with the increasing doses of fertilizers. Thus, in tubbing 
stage the number of bacteria had increased from 20.0 million/g soil in control to $39.7 \mathrm{~m} / \mathrm{g}$ soil in variant with $\left.\mathrm{N}_{90} \mathrm{P}_{90} \mathrm{~K}_{90}\right)$. However, the intensity of bacteria growth had decreased in all experimental variants under the influence of microbial preparation except for the variant without fertilizers (Fig. 2).

These features might be explained by the decrease of the trophic substrate in root zones of bacterized plants due to the more intensive assimilation of mineral nitrogen. The improvement of the assimilation degree of nitrogen fertilizer in bacterized plants was previously shown in experiments with the heavy stable isotope ${ }^{15} \mathrm{~N}[9]$.

Experimental data had shown the growth of nitrogen fixing bacteria at tubing stage from $282,500.0$ thousand / $\mathrm{g}$ dry soil in control to 508,500.0 thousand / $\mathrm{g}$ dry soil in variants with the lowest dose of fertilizer used $\mathrm{N}_{30} \mathrm{P}_{30} \mathrm{~K}_{30}$. The same effect was observed during blooming stagein the variants with the average doses of mineral fertilizers - 1064.0 thousand / g dry soil as compared to 734.5 thousand / $\mathrm{g}$ dry soil. At the end of the growing season of winter wheat plants an increase in the number of nitrogen fixing bacteria was observed from 862.5 thousand / g dry soil in control to 10640.0 thousand / g dry soil in the variant with $\mathrm{N}_{60} \mathrm{P}_{60} \mathrm{~K}_{60}$ doses of mineral fertilizers (Table 1). Plants bacterization with Polymyxobacterin had no effect on the growth of nitrogen fixing bacteria since the plant growth stimulating bacterium Paenibacillus polymyxa KB (active agent of microbial preparation Polymyxobacterin) does not fix atmospheric nitrogen.

Developmental dynamics of denitrifying bacteria had indicated that application of high doses of fertilizers contributes to the increase of their number during all growth phases of winter wheat plants. However, the use of Polymyxobacterin induces some changes. Thus, the number of denitrifying bacteria in root zones of winter wheat plants had decreased. For example, at the phase of milky-wax ripeness in variants with Polymyxobacterin and mineral fertilizers $\mathrm{N}_{60} \mathrm{P}_{60} \mathrm{~K}_{60}$ the number of denitrifying microorganisms was 4,995.0 thousand/g soil, while in variant without bacterization on the same background the number of studied bacteria had reached 8,400.0 thousand / g soil (Table 2).

The effect of the microbial preparation on the reduction of the number of denitrifying bacteria can be explained by the fact that winter wheat plants initiated with bacterization had developed more intensively, utilizing more nitrogen from fertilizers, thereby depriving nitrate respiration substrate for denitrifying bacteria. For sure, this effect will be observed only at application of physiologically appropriate doses of mineral nitrogen. 


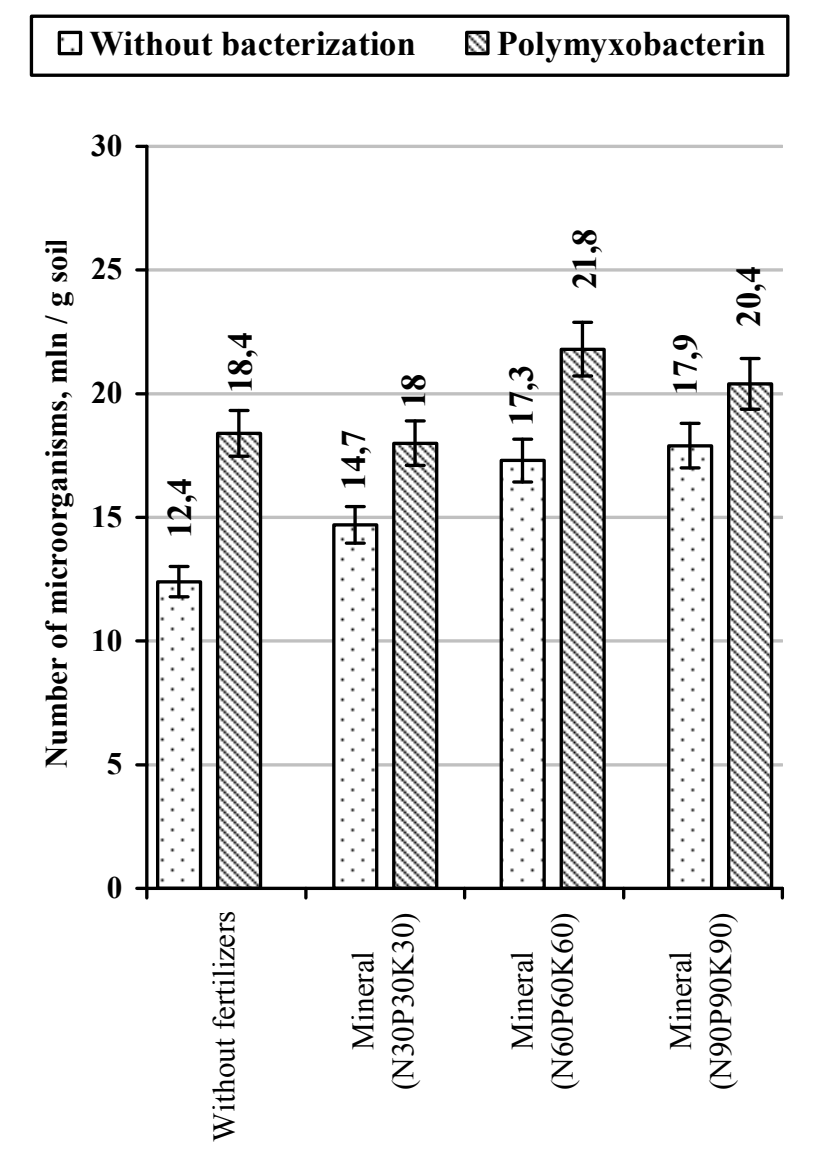

Variants

Tubing stage

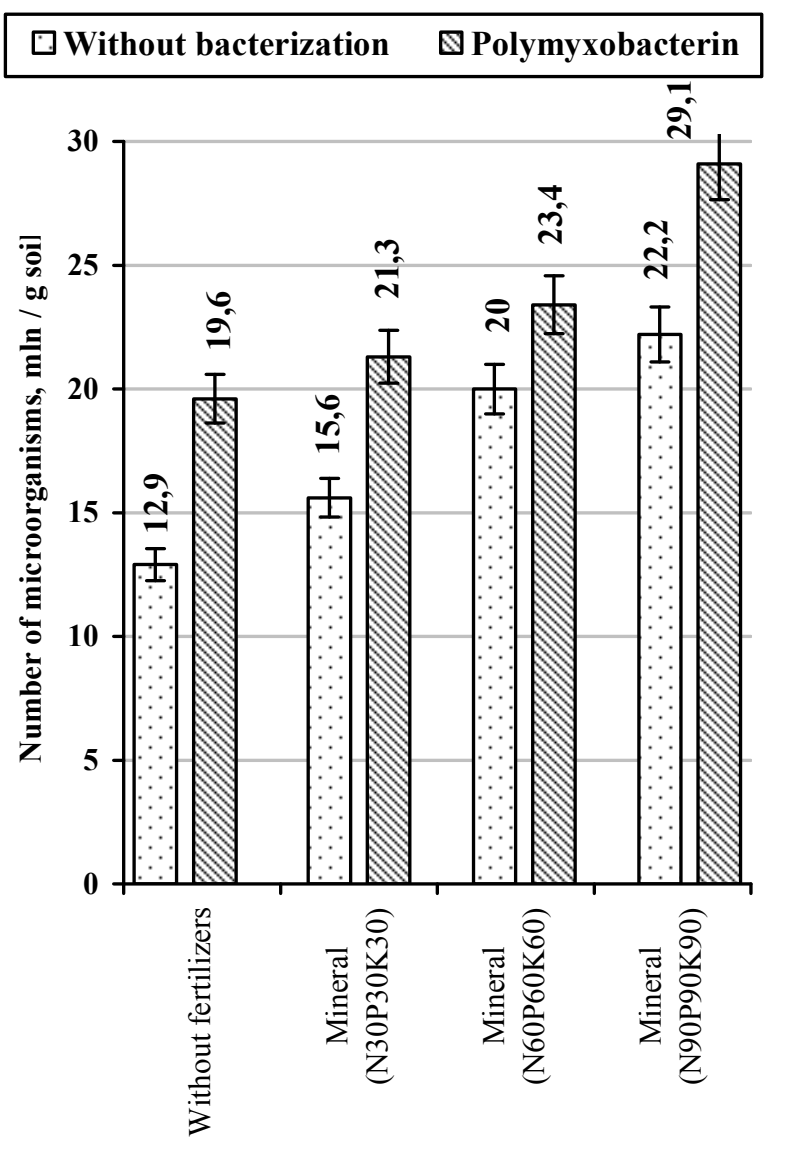

Variants

Flowering stage

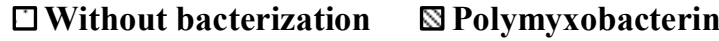

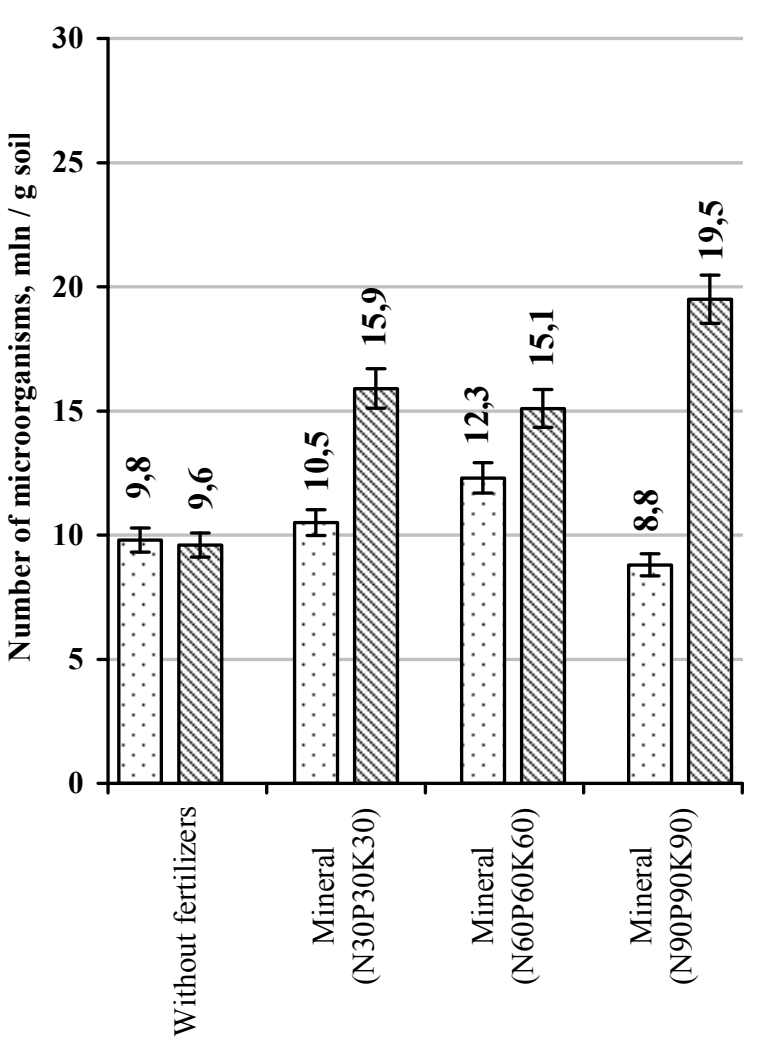

Variants

Milky-wax stage

Fig. 1. Influence of bacterization and fertilizers on the number of ammonifier bacteria in rhizosphere soil of winter wheat plants of Sonechko variety 


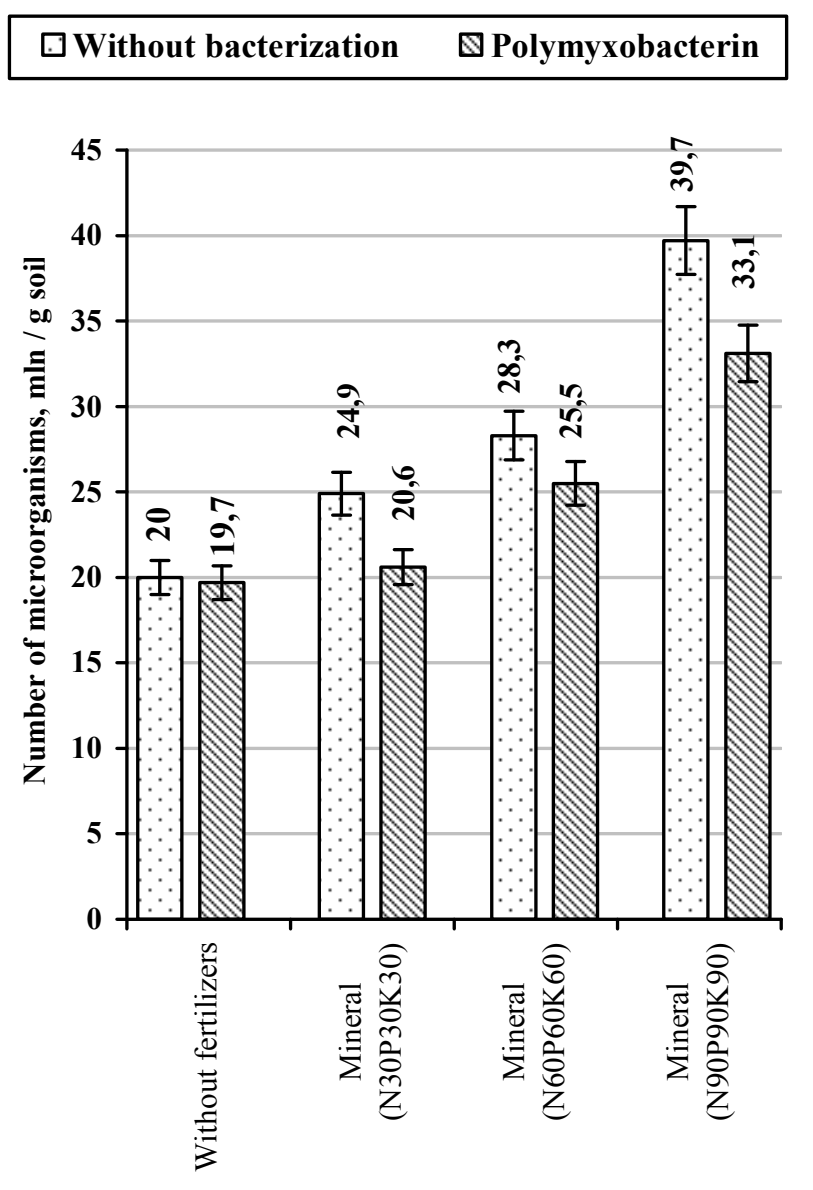

Variants

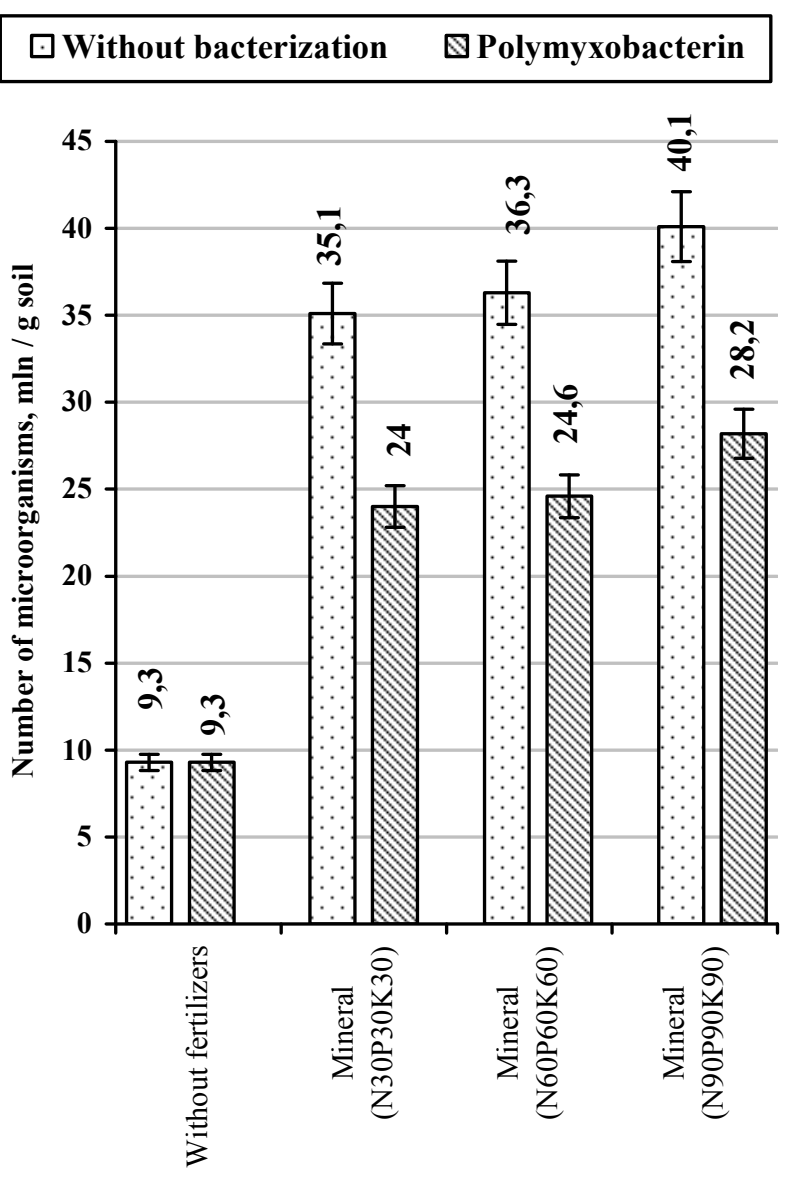

Variants

\section{$\square$ Without bacterization $\quad$ P Polymyxobacterin}

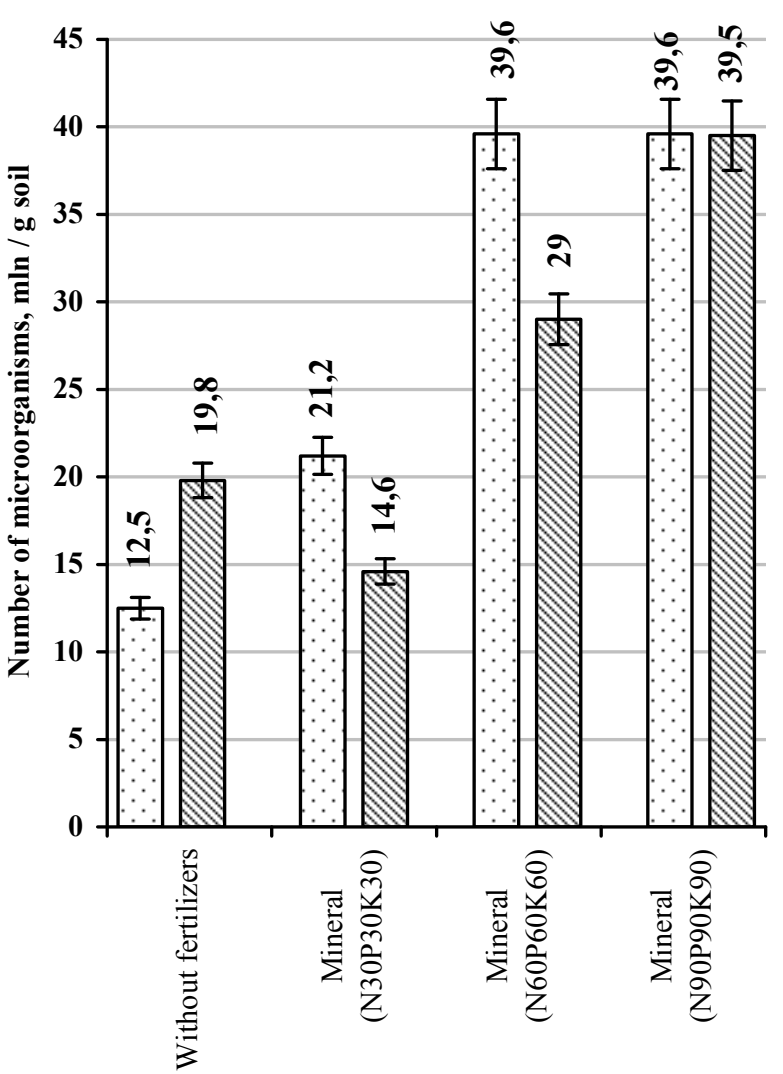

Variants

Tubing stage

Flowering stage

Milky-wax stage

Fig. 2. Influence of bacterization and fertilizers on the number of microorganisms that utilize mineral forms of nitrogen in rhizosphere soil of winter wheat plants of Sonechko variety 
Table 1. Influence of bacterization and fertilizers on the number of nitrogen fixing bacteria in rhizosphere soil of winter wheat plants of Sonechko variety, thousand / g dry soil

\begin{tabular}{|c|c|c|c|}
\hline Variants & Tubing stage & Flowering stage & Milky-wax stage \\
\hline \multicolumn{4}{|c|}{ Without bacterization } \\
\hline Without fertilizers (control) & 282500,0 & 734,5 & 862,5 \\
\hline $\mathrm{N}_{30} \mathrm{P}_{30} \mathrm{~K}_{30}$ & 508500,0 & 832,5 & 1083,0 \\
\hline $\mathrm{N}_{60} \mathrm{P}_{60} \mathrm{~K}_{60}$ & 339000,0 & 1064,0 & 10640,0 \\
\hline $\mathrm{N}_{90} \mathrm{P}_{90} \mathrm{~K}_{90}$ & 226000,0 & 840,0 & 2825,0 \\
\hline \multicolumn{4}{|c|}{ Bacterization with Polymyxobacterin } \\
\hline Without fertilizers & 224000,0 & 728,0 & 847,5 \\
\hline $\mathrm{N}_{30} \mathrm{P}_{30} \mathrm{~K}_{30}$ & 508500,0 & 840,0 & 1680,0 \\
\hline $\mathrm{N}_{60} \mathrm{P}_{60} \mathrm{~K}_{60}$ & 282500,0 & 1288,0 & 12210,0 \\
\hline $\mathrm{N}_{90} \mathrm{P}_{90} \mathrm{~K}_{90}$ & 280000,0 & 1064,0 & 2775,0 \\
\hline
\end{tabular}

Table 2. Influence of bacterization and fertilizers on the number of denitrifying bacteria in rhizosphere soil of winter wheat plants of Sonechko variety, thousand / g dry soil

\begin{tabular}{|c|c|c|c|}
\hline Variants & Tubing stage & Flowering stage & Milky-wax stage \\
\hline \multicolumn{4}{|c|}{ Without bacterization } \\
\hline Without fertilizers (control) & 2800,0 & 7345,0 & 2875,0 \\
\hline $\mathrm{N}_{30} \mathrm{P}_{30} \mathrm{~K}_{30}$ & 2825,0 & 8325,0 & 2850,0 \\
\hline $\mathrm{N}_{60} \mathrm{P}_{60} \mathrm{~K}_{60}$ & 8475,0 & 10640,0 & 8400,0 \\
\hline $\mathrm{N}_{90} \mathrm{P}_{90} \mathrm{~K}_{90}$ & 10735,0 & 16800,0 & 10735,0 \\
\hline \multicolumn{4}{|c|}{ Bacterization with Polymyxobacterin } \\
\hline Without fertilizers & 2240,0 & 7280,0 & 508,5 \\
\hline $\mathrm{N}_{30} \mathrm{P}_{30} \mathrm{~K}_{30}$ & 2825,0 & 8400,0 & 1064,0 \\
\hline $\mathrm{N}_{60} \mathrm{P}_{60} \mathrm{~K}_{60}$ & 10070,0 & 10640,0 & 4995,0 \\
\hline $\mathrm{N}_{90} \mathrm{P}_{90} \mathrm{~K}_{90}$ & 10640,0 & 16800,0 & 8325,0 \\
\hline
\end{tabular}

Analysis of the quantity dynamics of microorganisms that transform nitrogen compounds in rhizosphere soil of winter wheat plants of Sonechko variety indicates the positive effect of mineral fertilizers in doses not exceeding $\mathrm{N}_{60} \mathrm{P}_{60} \mathrm{~K}_{60}$ on changes in groups of microorganisms. Further increase of level of mineral fertilization ensures negative fluctuations in the microbial composition - growth of number of microorganisms that utilize mineral forms of nitrogen and denitrifying bacteria, followed by the reduction of number of nitrogen fixing bacteria. Microbial preparation was shown to be an important factor influencing the state of microbial communities. It was shown that plants bacterization with Polymyxobacterin had enhanced mineral nutrition of plants, followed by decrease of quantity of denitrifying bacteria and microorganisms, that utilize mineral forms of nitrogen. 